\begin{tabular}{|c|cc|c|}
\hline $\begin{array}{c}\text { PORT SAID ENGINEERING RESEARCH JOURNAL } \\
\text { Faculty of Engineering-Port Said University }\end{array}$ & $\begin{array}{l}\text { No.2 } \\
\text {-Architectural Engineering- }\end{array}$ \\
\hline
\end{tabular}

\title{
A Suggested Tool for Boosting Efficiency of Donor Policy in Tenders of Construction Projects in Egypt
}

\author{
Walaa A. Yakoub ${ }^{\text {I\&2 }}$
}

\begin{abstract}
Contractors usually have a significant role in construction projects' success; thus, the right choice of contractor is a decisive mission of the project's owner, which generally has a great effect on the success of a construction project. While the donor policy in bidding to the lowest price one in construction sector is very critical issue as it is considered as a risk that cause deviation occurrence negatively and indirectly of the cost of construction projects. Cost saving and reduction should start with the method of contractors' choice as it is not confined to financial aspects only but also, technical, managerial, project resources and political aspects. The purpose of this paper is to present an approach (CPCME) that can assess the bidders after filling their assessment and evaluation forms (A proposed checklist adopts AHP method), then comparing among them by the total of collected points for each form. Finally, it can be easily to select a contractor, but acutely it is important to select the most qualified one.
\end{abstract}

Keywords: Contractors, Tool, Competitive tendering, Donor Policy, Construction Projects.

\section{INTRODUCTION}

Nowadays, a major literature arises on the effective impact of successful project management on construction projects [1], whereas, the construction industry is concerning with important issues; one of them is the way to select and assess the contractors (bidders). As it's concluded that increases in the cost of project (cost overrun) can be considered as direct result of this problem and it was noticed that belonged to the ability of contractors to execute the projects without bearing cost overburden [2]. So, it requires utilization of a systematic approach can be able to assess and evaluate the contractors instead of the traditional way of contractors' selection; consequently, this paper discusses a proposed approach assessing the contractors in the bidding phase of construction projects in Egypt.

\section{The Problem of Assessment Progress of Contractors in Egypt}

The recent pivotal problem represents in the question; what is the best methodology for contractor's selection process? unfortunately, the philosophy of 'the lowestprice wins' has been a consistent theme of contractor selection over the years [3]. Hence, nominating a proper contractor is one of the most important issues owners of construction projects have to face to reach satisfactory project outcomes. But, using bid prices as the only indicator in contractor selection process is mostly followed in countries around the world.

\footnotetext{
1 The Department of Architecture \& Urban Planning, Faculty of Engineering, Port Said University, Egypt

${ }^{2}$ The Department of Architectural Engineering, Faculty of Engineering, Horus University- Egypt
}

Received: 28-09-2020, Accepted: 24-02-2021

DOI: $10.21608 /$ PSERJ.2021.44347.1066
The lowest price of bid does not necessarily concern merit for the project's owner as the quality and duration of a construction project might be affected negatively [4], so that, this is the main problem of the current research is that why the researcher tries to solve this hard equation of bidders' selection, so, the main problems of current contractor selection methods in Egypt aren't depend on the skill, and experience. The criteria controlling decision-making in tenders differs from one to another and there are not certain standards, yet which guarantee the quality of the evaluation and nomination processes of bidders [5]

Besides, the large number of contractors in a few numbers of construction projects leads to strong competition among them. Consequently, selecting the appropriate contractor is a difficult decision to the project owner, as, accepting lowest price bid is the main reason for project obstacles' occurrence because of decreasing the price directly means decreasing the level of quality, so, properly evaluation of the contractor's capabilities, in addition to, helping contractor to obtain an effective pricing method leading to expect the actual cost and become the ideal solutions for problem of contractor's nomination. Consequently, the project's owners should depend on a scientific methodology in this process instead of donor policy in bidding to the lowest price to guarantee executing the project without any financial obstacles and delay [6].

Moreover, this study targets to create a model for bidders' nomination process of construction projects and nominate the appropriate contractor whose, the best file not having the lowest price as usual in the construction sector, which can upgrade the construction industry in Egypt, in addition to finding a suitable standards structure that helps in the successful selection of contractors to be invited to apply for the tender and those who are able to 
implement the project and complete it successfully and then choose the offer Best. It can be done in two phases: Contractor`s prequalification and final selection when bid evaluation $[7] \&[8]$.

\subsection{The Traditional Method of Assessing the Contractors in Egypt}

Tendering is a process holding among a group of bidders to choose the best one of them, basically, there are varied types of tenders like; open tendering and, selective/restricted tendering [9]. The first chapter of the Egyptian law no 89 of 1998 is concerning with contacting in particular the item no 57 which clarified that bidders should present the technical file included all required technical info and documents [10]. Most of current methods used in selecting the bidders focus on accepting the lowest bid price, as the lowest tender price is usually described as a key of winning the targeted contract [11]\&[12]. So, the bidding process is critical stage as decision makers are required to evaluate bidders in terms of technical aspects as; the proposed design, construction technique, and the used materials, the donor policy in bidding to the lowest price. Moreover, it's preferable to use an aiding tool to guarantee achieving the goal of cost reduction within preparing lists of potential risks that affecting contractors' assessment process in Egypt.

\subsection{Insufficiency of the Traditional Method of Contractor's Assessment Process in Egypt}

Although, contractors worldwide follow many strategies to improve their chances of winning bids. They take into consideration many factors such as: market conditions, skills, and management experts to produce a detailed cost estimate [13]. In Egypt, granting a contract is still to the lowest bid price, without adopting other indicators, lead to many problems as; cost overruns, delay in project timeline and unsatisfied performance as followed in other countries [10]. Hence, accepting the lowest price in bid evaluation is the prime reason for project delivery problems, as contractors desperately quote low prices by reducing their quality of work, and hope to be compensated by submitting 'claims', hence, the lowest bidders fail to complete projects due to financial difficulties or other common grounds [14], consequently, owners and consultants should adopts other effective ways in assessing and evaluating contractors; several types of contractor's selection methodologies can be used as shown in figure (1):

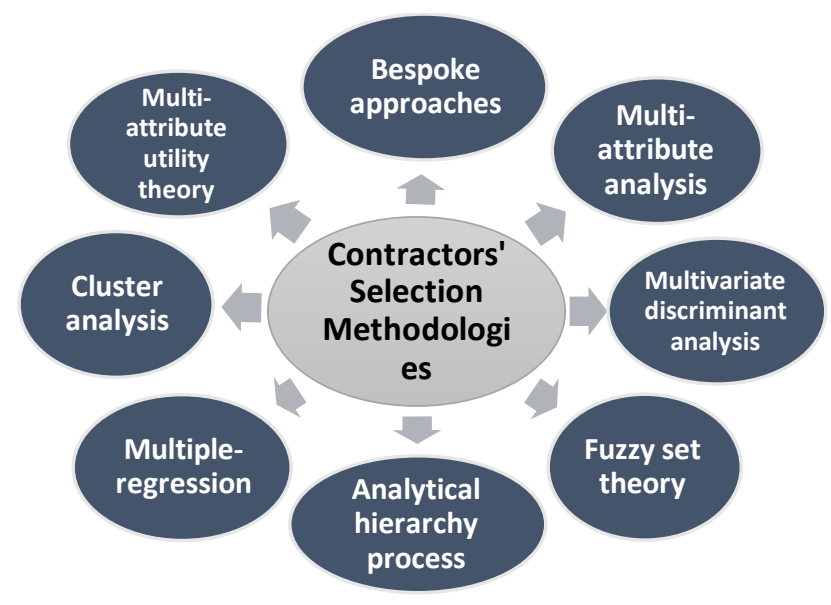

Figure 1: Methodologies of contractors' selection,

The researcher after [15]

\subsection{The Importance of Selecting the Appropriate Contractor}

There's little question that construction society awareness of the necessity for proper contractor selection is rising recently [15], hence, selecting a qualified construction contractor is one among the foremost serious issues faced by a project owner who aims to realize succeeded project findings. Often this mission is confronting because the development manufacturing is unsteady and very competitive. Additionally, the likelihood of project's failure is classified of high for solo contractor, and it's vital for clients to face and organize these perils if they intent to realize satisfied project outcomes [11]. Moreover, with a correct bid-evaluation system, the owner for a given work, good, or service would be ready to select competent, financially capable, and experienced contractors [16]. As, the quality of contractor progress is considered important for the owner's contentment. The aims of project's owner are associated with the project sides: cost, time, and quality. On the idea of those main aspects, an inventory of indicators are often produced [4]. Also, contractors would be ready to decide whether or not they should bid on a project [17].

Finally, almost previous studies affirmed that tendering process must simplify choosing the right contractor with regarding many factors. Besides, avoiding objections from the bidders, bid assessment process must base on credible data and performed in an impartial way [18].

\section{Previous Studies of Contractors' Assessment Methods}


Table1: Literature review about contractors' assessment process

\begin{tabular}{|c|c|c|}
\hline Author & $\begin{array}{l}\text { Their opinions about contractor's } \\
\text { assessment process }\end{array}$ & $\begin{array}{c}\text { Extracted criteria of contractor's assessment } \\
\text { process }\end{array}$ \\
\hline $\begin{array}{l}\text { Holt et al } \\
\text { (1995) }\end{array}$ & $\begin{array}{l}\text { Suggested more groups of criteria, standards, and } \\
\text { techniques to use in the assessment process of } \\
\text { bidders. }\end{array}$ & $\begin{array}{l}\text { Clarified that suitable price, experience, technologies, and } \\
\text { plants belong to company are the main factors determine } \\
\text { the effectiveness of contractors }\end{array}$ \\
\hline $\begin{array}{l}\text { Kumaraswamy } \\
\text { (1996) }\end{array}$ & $\begin{array}{l}\text { Stated that Public Sector always must choose the } \\
\text { lowest bidder (the bidder whose lowest price of } \\
\text { tender). }\end{array}$ & $\begin{array}{l}\text { Evaluate Tenders based on Price, Capabilities and } \\
\text { Past-Performance of the bidders }\end{array}$ \\
\hline $\begin{array}{l}\text { I.Mahdi et al } \\
\text { (2002) }\end{array}$ & $\begin{array}{l}\text { Saw that the assessment process of contractors } \\
\text { should depend on varied aspects concerning the } \\
\text { nature of project also, it is recommended to be } \\
\text { simple, accurate and transparent. }\end{array}$ & $\begin{array}{l}\text { Mentioned that in selecting a contractor varied criteria for } \\
\text { bidder's selection like; experience, overall performance in } \\
\text { former construction projects, financial strength, etc., should } \\
\text { be considered simultaneously. }\end{array}$ \\
\hline $\begin{array}{l}\text { Cheng and } \mathrm{Li} \\
(2004)\end{array}$ & $\begin{array}{l}\text { Proposed an assessment tool called (MCDM) as } \\
\text { an important method that can help decision } \\
\text { makers in selecting the appropriate contractor, } \\
\text { depending on the (AHP) method. }\end{array}$ & $\begin{array}{l}\text { The taken decision based on many factors as; fit price, } \\
\text { former experience, the financial situation of company and } \\
\text { Technology capacity. }\end{array}$ \\
\hline $\begin{array}{lll}\text { Elhag, et al. } \\
(2005)\end{array}$ & $\begin{array}{l}\text { Stated that the quantitative indicators are } \\
\text { preferable to be taken into consideration within } \\
\text { the estimation process for tender prices. }\end{array}$ & $\begin{array}{l}\text { The assessment elements represent in the amount of work, } \\
\text { the bidding price, Statement of pre and post costs for } \\
\text { previous implemented projects, technology capacity. }\end{array}$ \\
\hline $\begin{array}{l}\text { Shen et al } \\
(2006)\end{array}$ & $\begin{array}{l}\text { Identified the key competitiveness indicators } \\
\text { (KCIs) for assessing contractor competitiveness } \\
\text { in the Chinese construction market. An index } \\
\text { value is used to indicate the relative significance } \\
\text { of various competitiveness indicators based on } \\
\text { which KCIs are identified. }\end{array}$ & $\begin{array}{l}\text { Stated a lot of factors influencing contractor assessment } \\
\text { process as; bidding price, the time line of project, the set } \\
\text { plan for project Quality, Environment protection plan, } \\
\text { Safety plan, Construction method, Experience in operating } \\
\text { similar projects, Plant availability, Availability of key } \\
\text { personnel, Financing ability, Financial stability, Financial } \\
\text { status, Bank credit, Technology capacity, Technology } \\
\text { development plan, Plant and equipment resources, } \\
\text { Information technology, Relationship with governmental } \\
\text { departments, Relationship with project clients, Relationship } \\
\text { with subcontractors and suppliers, Relationship with the } \\
\text { public, an Effectiveness systems of quality, time, cost, } \\
\text { human resources and, contracts management, besides, the } \\
\text { good reputation of the company. }\end{array}$ \\
\hline $\begin{array}{lll}\text { Azimi } & \text { et. } \quad A l \\
(2013) & \end{array}$ & $\begin{array}{l}\text { Clarified that the process of contractor's selection } \\
\text { must depend on the technique of Analytical } \\
\text { Hierarchy Process. }\end{array}$ & $\begin{array}{l}\text { Mentioned that bidding price, used technology, experience, } \\
\text { quality, time, cost management are the main factors } \\
\text { influencing the decision of contractors' nomination. }\end{array}$ \\
\hline $\begin{array}{l}\text { Hsueh \& Yan } \\
(2013)\end{array}$ & $\begin{array}{l}\text { Stated that the analytic hierarchy process (AHP) } \\
\text { is the targeted assessment method }\end{array}$ & $\begin{array}{l}\text { This study successfully combines four scientific } \\
\text { methodologies to develop a contractor assessment model; } \\
\text { Number of constructors, Green innovation, Corporate } \\
\text { social responsibility and, Output value (profit). }\end{array}$ \\
\hline $\begin{array}{l}\text { Ruparathna\& } \\
\text { Hewage: }(2015)\end{array}$ & $\begin{array}{l}\text { Mentioned that a set of integrated indicators } \\
\text { (checklist) should determine the process of } \\
\text { contractor's selection. }\end{array}$ & $\begin{array}{l}\text { Stated that the assessment process in tenders need an } \\
\text { integration of all economic, social and environmental } \\
\text { indicators in terms of the process of award contractors. }\end{array}$ \\
\hline $\begin{array}{lll}\text { Deep } & \text { et } \quad \text { al., } \\
(2017) & \end{array}$ & $\begin{array}{l}\text { Reviewed that the contractors' selection process } \\
\text { mostly depends on the lowest proposed price. In } \\
\text { addition to take some items in consideration as; } \\
\text { time delays, the efficiency of contractor, } \\
\text { suitability of the price, and the company's } \\
\text { reputation. }\end{array}$ & $\begin{array}{l}\text { Mentioned a lot of factors as; the bidding price, the period } \\
\text { of execution of projects, projects Quality, Safety plan, } \\
\text { Construction method, Experience in operating similar } \\
\text { projects, contracts management. }\end{array}$ \\
\hline Leśniak, (2018) & $\begin{array}{l}\text { Proposed a system depends on Fuzzy Analytic } \\
\text { Hierarchy Process (FAHP) to promote the } \\
\text { decision making in tenders. }\end{array}$ & $\begin{array}{l}\text { Clarified that Company capabilities, Investment } \\
\text { characteristics, Financial and, Tender characteristics are the } \\
\text { main criteria for tender selection. }\end{array}$ \\
\hline $\begin{array}{l}\text { Hoseinpoor \& } \\
\text { Alborzi } \\
(2019)\end{array}$ & $\begin{array}{l}\text { The determined weights of criteria using AHP } \\
\text { Group method. }\end{array}$ & $\begin{array}{l}\text { Affirmed that Past same works, experience, Equipment, } \\
\text { efficient labor and powerful economic situation are to } \\
\text { Evaluate the competence of contractors. }\end{array}$ \\
\hline $\begin{array}{l}\text { Cheng et al } \\
(2020)\end{array}$ & $\begin{array}{l}\text { Proposed an innovative decision-making system } \\
\text { of contractor selection and an index weight- } \\
\text { assessing system for sustainable development }\end{array}$ & $\begin{array}{l}\text { Determined the most Influencing factors on the bid } \\
\text { commitment represent in Duration, Cost and Quality. }\end{array}$ \\
\hline $\begin{array}{l}\text { Kumar \& Rai } \\
\text { (2020) }\end{array}$ & $\begin{array}{l}\text { There is a standard data collection technique } \\
\text { being employed by the researchers where the } \\
\text { required data or the factors influencing bid } \\
\text { decisions are obtained through a structured } \\
\text { questionnaire survey. }\end{array}$ & $\begin{array}{l}\text { The factors influencing the decision making of the bidders } \\
\text { at earlier time of bidding were most important as; technical } \\
\text { competence, project management capability and } \\
\text { understanding procurement tasks. }\end{array}$ \\
\hline
\end{tabular}


Source: The researcher after [19];[20];[21];[22];[23];[24];[25];[26];[27];[28];[29];[30] [31] \& [32]

Although the opinions of authors in previous studies are varied among nominating checklist, choosing the lowest price bid or depending on AHP method in assessing contractors, the researcher agreed with the previous point of views of former researches in particular, [22], [25], [26], [29] \& [30] and look for an optimum method as AHP method which is effective, convenient and easy to select a contractor to stop from obstacles within the project execution.

\section{The Proposed Approach to Nominate Contractors (Bidders) in Egypt}

Prequalification and bid evaluation procedures are currently used in many countries and involve many various sorts of criterion to assess whole suitability of contractors. For example, general, technical, managerial, and financial criteria [33], hence, the progression of a better choosing method is vital for succeeded projects' outcomes. The contractor nomination process using many standards that could outdo the tradeoff in bid value by quantitative criteria can be considered. So, the researcher seeks to find a correct method for evaluating the contractor's instead of the donor's policy of the lowest price bid. This form was designed to enable the organization to choose the right bidders (Contractors) based on a result of a former study of the researcher. The initial idea of this weighting system refers to Rita book, recommended with using the next table as a weighting system for evaluating and selecting the contractor/ supplier at the bidding phase according to the evaluation criteria. Hence, the owner can compare contractors to choose the best meet the criteria [2].

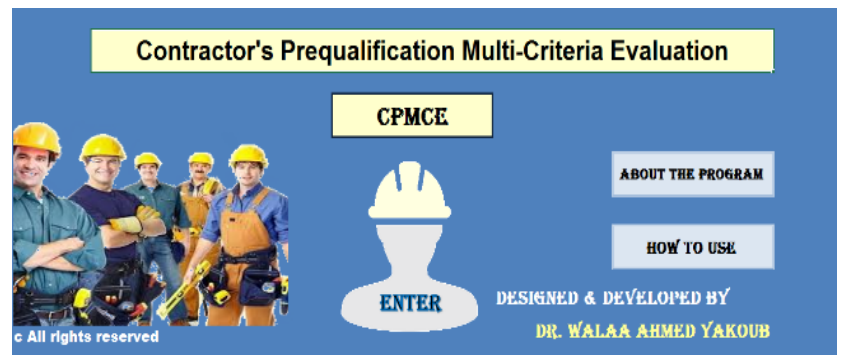

Figure 2: Opening window of CPMCE program

The researcher designed and developed a calculation sheet by (Microsoft Spreadsheet) and named it; Contractor's Prequalification Multi-Criteria Evaluation (CPMCE) as an AHP based assessment model to enable the project's owner or consultant to select the appropriate contractor (Bidder) in case of existence of the determined files (Five mandatory files) shown in the following figures:

The initial idea of this weighting system refers to Rita book, recommended with using the next table as a $1^{\text {st }}$ Step: Access to CPMCE

$2^{\text {nd }}$ step: Filling the FFP

$3^{\text {rd }}$ step: Processing by AHP Method

Final result: the nominated contractor

Figure 3: Steps of the proposed idea

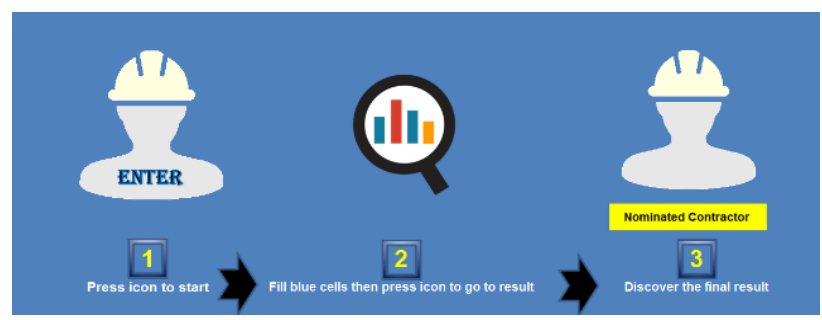

Figure 4: Followed steps on CPMCE

weighting system for evaluate and select the contractor/ supplier at the bidding phase according to the evaluation criteria, hence, the owner can compare contractors to nominate the best meet the criteria. Moreover, many approaches used in weighting process such as; cell weighting, raking, linear weighting, GREG weighting, logistic regression weighting, truncated linear weighting... etc [34], which motivate the researchers to set their own weightings using cell weighting method considering the opinions of contributed contractors; about 65 respondents at different conractings companies in PortSaid city assess the relative impatrance of the collected 37 factors included in the assessment document. The researcher finds that the final product of assessment process of contractors in Egypt (the proposed assessment model) can represent in a weighting system like that shown in table (2) as follow:

Table 2: Example of weighting system

\begin{tabular}{|l|l|l|l|}
\hline Seller no. & A & B & C \\
\hline Criteria & Weight & $\begin{array}{l}\text { Rating for } \\
\text { this category }\end{array}$ & $\begin{array}{l}\text { Category } \\
\text { score }\end{array}$ \\
\hline $\begin{array}{l}\text { Number of years } \\
\text { in business }\end{array}$ & $\%$ & & A*B \\
\hline \multicolumn{2}{|l|}{ Total score of this seller } & $\sum_{n=1} \mathrm{~A} * \mathrm{~B}$ \\
\hline
\end{tabular}

The researcher after [35]

A lengthy explanation and findings of study conducted in Egypt can be found in the former study of the researcher that depending on a survey by a set of Egyptian contractors were targeted to contribute in collecting pertinent data from respondents a questionnaire contains two main sections was fabricated. The first section contains questions belonging to the contributing 
construction company, consequently, permitting to set an abbreviated description for the participating contractors in this research. The second section contains many questions considering the degree of the impact of the probable indicators on the decision of bid or not to bid.

\subsection{AHP Method: A Corner Stone in the Assessment Process of Bidders}

This research adopts Analytical Hierarchy Process to evaluate and sort the contractors according to certain determined indicators. Finally, the suitable contractor chosen and declared to the winner contractor.

A simple AHP hierarchy, with final priorities [30]. The goal is to select the most suitable contractor from a field of three candidates for example shown in Fig (5). The factors to be considered are the determined files clarified in FFP model. According to the judgments of the decision makers, Bidder 1 is the strongest candidate, followed by Bidder 2, then Bidder 3.

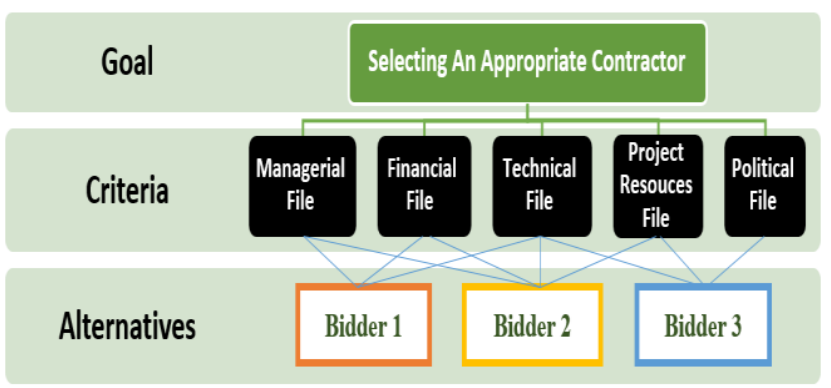

\section{Figure 5: AHP based bidders' assessment process}

Based on the response plan belonging to former study, the researcher noticed that the avoidance of traditional methods in contractors' choice from managerial, technical, and financial aspects in particular. As the donor policy to the lowest price was ranked to be the most factor influencing in the project costs. Consequently, the researcher tried to create a new model for contractor evaluation which based on a scientific method and suggested that there is an urgent need to choose a scientific tool to nominate the appropriate contractor.

The proposed smart model (check list) which can evaluate and assess the contractor (bidder) in the bidding phase of construction project, so it became covering all the aspects Whether Administrative, financial, technical, That can clarify various aspects of the construction companies to identify its evaluation before contracting. That suggestion can answer the research question. So, AHP represents an accurate approach for quantifying the weights of decision criteria depending on the values of relative importance of assessed files for each contractor.

\subsection{Criteria for Contractors' Evaluation Process}

Determination of criteria of contractors' assessment and evaluation process has a pivotal role in this study, so, the researcher seeks to conduct a comprehensive study about those criteria as follow in table (3):
The researcher collected about Thirty-Seven criteria under five main groups involved in contractor selection were gathered from literature review and put into major underlying factors. This Model has been developed for construction companies, it consists of a group of major and minor standards which could prior assessment for those companies, these standards have been formulated as questions to be displayed on the specialists and experts in the field of building and construction to take their views on the major and minor standards in the proposed model to evaluate construction companies to clarify if these standards have been overlooked which fit for specificity of construction projects. This evaluation form is shown in Appendix (A), whereas the researcher presents the major and minor standards of contractor evaluating in table (4).

\section{FFP Model}
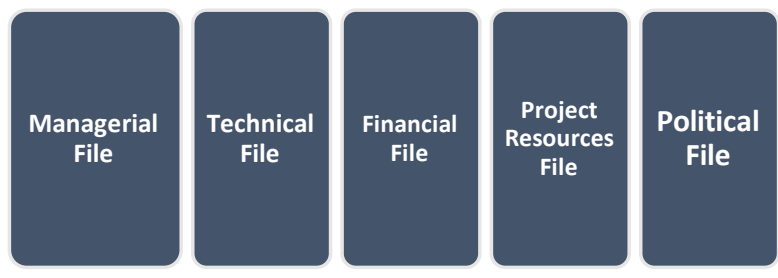

\section{Figure 6: Major standards of contractor evaluation}

Moreover, the contractor is to submit a replica of this form and other required documents to the Contractors and Consultants Classification Administration. Consequently, contractor may be completely responsible for the accuracy of the information submitted for classification. In addition, the contractor must impart any changes that may affect the technical and financial capabilities or any change to its legal status. Besides, the contractor must attest all the submitted forms and documents and the owner of the project has the right to verify their authenticity.

Table 4: Major and minor standards of contractor evaluation (FFP model)

\begin{tabular}{|c|c|l|}
\hline $\begin{array}{c}\text { Major } \\
\text { Standard }\end{array}$ & Code & \multicolumn{1}{|c|}{ Minor Standard } \\
\hline \multirow{4}{*}{} & $\mathbf{X 1 - 1}$ & $\begin{array}{l}\text { Statement of pre and post costs for } \\
\text { previous implemented projects }\end{array}$ \\
\cline { 2 - 3 } & $\mathbf{X 1 - 2}$ & $\begin{array}{l}\text { Approval the binding contractual } \\
\text { conditions to deliver the project on } \\
\text { required time and Fines apply in } \\
\text { case of delay }\end{array}$ \\
\cline { 2 - 3 } & $\mathbf{X 1 - 3}$ & $\begin{array}{l}\text { Presence of modern techniques for } \\
\text { cost estimation }\end{array}$ \\
\cline { 2 - 4 } & $\mathbf{X 1 - 4}$ & $\begin{array}{l}\text { Ability to plan and schedule the } \\
\text { technical operations of the projects } \\
\text { by modern technology }\end{array}$ \\
\cline { 2 - 3 } & $\mathbf{X 1 - 5}$ & $\begin{array}{l}\text { Monitoring and evaluation system } \\
\text { of carried out work in the project }\end{array}$ \\
\cline { 2 - 3 } & $\mathbf{X 1 - 6}$ & $\begin{array}{l}\text { Statement of administrative } \\
\text { structure of the contracting } \\
\text { company }\end{array}$ \\
\cline { 2 - 3 } & $\mathbf{X 1 - 7}$ & Presence of insurance certificate on \\
\hline
\end{tabular}




\begin{tabular}{|c|c|c|}
\hline & & the project \\
\hline & X1-8 & $\begin{array}{l}\text { Availability of Fire Protection and } \\
\text { Alarms Systems }\end{array}$ \\
\hline \multirow{12}{*}{ 宸 } & $\mathrm{X} 2-1$ & Presence of value estimator \\
\hline & $\mathrm{X} 2-2$ & $\begin{array}{l}\text { Statement of technical structure of } \\
\text { the contracting company }\end{array}$ \\
\hline & $\mathrm{X} 2-3$ & $\begin{array}{l}\text { Presence of risk management } \\
\text { department }\end{array}$ \\
\hline & X2-4 & $\begin{array}{l}\text { The pledge of doing all required } \\
\text { soil tests and site investigation }\end{array}$ \\
\hline & $\mathrm{X} 2-5$ & $\begin{array}{l}\text { Presence of experienced supervisors } \\
\text { ( } \geq 10 \text { years) }\end{array}$ \\
\hline & X2-6 & $\begin{array}{l}\text { Presence of the work experience } \\
\text { certificate model }\end{array}$ \\
\hline & $\mathrm{X} 2-7$ & $\begin{array}{l}\text { Dealing with trustworthy } \\
\text { subcontractors }\end{array}$ \\
\hline & $\mathrm{X} 2-8$ & $\begin{array}{l}\text { Presence of valid classification } \\
\text { certificate }\end{array}$ \\
\hline & X2-9 & Presence of quality engineer \\
\hline & $\mathrm{X} 2-10$ & $\begin{array}{l}\text { Presence of valid membership of } \\
\text { EFCBC }\end{array}$ \\
\hline & $\mathbf{X 2 - 1 1}$ & $\begin{array}{l}\text { Absence of lawsuits against the } \\
\text { company }\end{array}$ \\
\hline & $\mathbf{X} 2-12$ & $\begin{array}{l}\text { Absence of previous accident } \\
\text { occurrence in work }\end{array}$ \\
\hline \multirow{7}{*}{ 苞 } & X3-1 & $\begin{array}{l}\text { Presence of continuity current bank } \\
\text { accounts without a break }\end{array}$ \\
\hline & X3-2 & $\begin{array}{l}\text { Detailed statement of fixed and } \\
\text { variable assets during the former } \\
\text { five years }\end{array}$ \\
\hline & $\mathbf{X 3 - 3}$ & $\begin{array}{l}\text { Massive volume of the company } \\
\text { cash money }\end{array}$ \\
\hline & X3-4 & $\begin{array}{l}\text { Valid membership of Egyptian } \\
\text { chamber of commerce }\end{array}$ \\
\hline & X3-5 & Presence of valid taxes declaration \\
\hline & X3-6 & Social insurance certificate \\
\hline & X3-7 & Presence of valid trade license \\
\hline \multirow{7}{*}{ 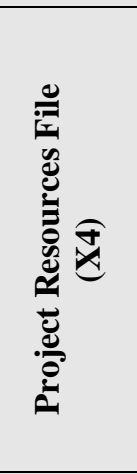 } & $\mathbf{X 4 - 1}$ & $\begin{array}{l}\text { Approval of fixed contracts for } \\
\text { materials prices }\end{array}$ \\
\hline & $\mathrm{X4-2}$ & Possession of materials' factories \\
\hline & $\mathrm{X4-3}$ & $\begin{array}{l}\text { List of suppliers who previously } \\
\text { dealt with }\end{array}$ \\
\hline & $\mathrm{X4-4}$ & $\begin{array}{l}\begin{array}{l}\text { Secured transport } \\
\text { materials }\end{array} \\
\text { malleys }\end{array}$ \\
\hline & $\mathbf{X 4 - 5}$ & $\begin{array}{c}\begin{array}{l}\text { Statement } \\
\text { equipment }\end{array} \\
\end{array}$ \\
\hline & $\mathrm{X4-6}$ & $\begin{array}{ll}\begin{array}{l}\text { Presence of } \\
\text { department }\end{array} & \\
\end{array}$ \\
\hline & $\mathrm{X4-7}$ & Labor insurances \\
\hline \multirow{3}{*}{ 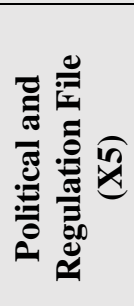 } & X5-1 & $\begin{array}{l}\text { The pledge of constantly working } \\
\text { during the revolutions, strikes, sit- } \\
\text { ins and any unforeseen } \\
\text { circumstances on the political } \\
\text { conditions of the country }\end{array}$ \\
\hline & $\mathrm{X5-2}$ & Guarding the site 24 hours a day \\
\hline & X5-3 & $\begin{array}{l}\text { The presence of fences around the } \\
\text { site }\end{array}$ \\
\hline
\end{tabular}

Source: The researcher after [2]

\subsection{Weightings of Main Criteria}

The sample taken from contractors' companies at classes (A \& B) in Port said city (the contractors who execute ten of recent tourist projects in the city as a case study of [2]) and after conducting closed interviews with engineers, projects managers, contractors and administrators, the researcher analyzed their opinions and rankings for the shown 37 items in tables $(5,6 \& 7)$ to sort them according to their priority using T-Test (Independent samples $\mathrm{T}$ Test) by SPSS vs 20.0.

Table 5: Relative frequency distribution table for different items and samples

\begin{tabular}{|c|c|c|c|c|c|c|c|}
\hline \multicolumn{2}{|c|}{ Engineers } & \multicolumn{2}{|c|}{$\begin{array}{c}\text { Project } \\
\text { managers }\end{array}$} & \multicolumn{2}{|c|}{ Contractors } & \multicolumn{2}{|c|}{ Administrators } \\
\hline Code & 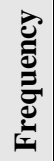 & Code & 总 & Code & 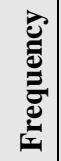 & Code & 总 \\
\hline X1-1 & 3 & X1-1 & 5 & X1-1 & 4 & X1-1 & 2 \\
\hline X1-2 & 5 & X1-2 & 4 & X1-2 & 5 & X1-2 & 4 \\
\hline X1-3 & 2 & $\mathrm{X} 1-3$ & 5 & X1-3 & 3 & X1-3 & 3 \\
\hline X1-4 & 4 & X1-4 & 3 & X1-4 & 2 & X1-4 & 2 \\
\hline X1-5 & 1 & X1-5 & 3 & X1-5 & 1 & X1-5 & 1 \\
\hline X1-6 & 2 & X1-6 & 4 & X1-6 & 3 & X1-6 & 1 \\
\hline X1-7 & 3 & X1-7 & 4 & X1-7 & 1 & X1-7 & 1 \\
\hline X1-8 & 1 & X1-8 & 4 & X1-8 & 1 & X1-8 & 1 \\
\hline X2-1 & 4 & X2-1 & 5 & X2-1 & 1 & X2-1 & 2 \\
\hline X2-2 & 3 & X2-2 & 4 & X2-2 & 2 & X2-2 & 1 \\
\hline X2-3 & 4 & X2-3 & 5 & X2-3 & 3 & X2-3 & 1 \\
\hline X2-4 & 4 & X2-4 & 5 & X2-4 & 1 & X2-4 & 1 \\
\hline X2-5 & 4 & X2-5 & 4 & X2-5 & 1 & X2-5 & 1 \\
\hline X2-6 & 2 & X2-6 & 3 & X2-6 & 3 & X2-6 & 1 \\
\hline X2-7 & 3 & X2-7 & 2 & X2-7 & 1 & X2-7 & 1 \\
\hline X2-8 & 2 & X2-8 & 2 & X2-8 & 1 & X2-8 & 2 \\
\hline X2-9 & 2 & X2-9 & 3 & X2-9 & 1 & X2-9 & 1 \\
\hline X2-10 & 2 & X2-10 & 2 & X2-10 & 2 & X2-10 & 1 \\
\hline X2-11 & 2 & X2-11 & 2 & X2-11 & 1 & X2-11 & 1 \\
\hline X2-12 & 1 & X2-12 & 2 & X2-12 & 1 & $\mathrm{X} 2-12$ & 1 \\
\hline X3-1 & 3 & X3-1 & 3 & X3-1 & 3 & X3-1 & 3 \\
\hline X3-2 & 2 & X3-2 & 4 & X3-2 & 3 & X3-2 & 2 \\
\hline X3-3 & 4 & X3-3 & 2 & X3-3 & 2 & X3-3 & 2 \\
\hline X3-4 & 4 & X3-4 & 5 & X3-4 & 1 & X3-4 & 1 \\
\hline X3-5 & 2 & X3-5 & 3 & X3-5 & 1 & X3-5 & 1 \\
\hline X3-6 & 3 & X3-6 & 2 & X3-6 & 1 & X3-6 & 1 \\
\hline X3-7 & 3 & X3-7 & 1 & X3-7 & 3 & X3-7 & 3 \\
\hline X4-1 & 1 & X4-1 & 1 & X4-1 & 3 & X4-1 & 2 \\
\hline X4-2 & 3 & X4-2 & 4 & X4-2 & 3 & X4-2 & 1 \\
\hline X4-3 & 2 & X4-3 & 3 & X4-3 & 2 & X4-3 & 2 \\
\hline X4-4 & 2 & X4-4 & 3 & X4-4 & 1 & X4-4 & 1 \\
\hline X4-5 & 1 & X4-5 & 3 & X4-5 & 1 & X4-5 & 1 \\
\hline X4-6 & 1 & X4-6 & 4 & X4-6 & 1 & X4-6 & 1 \\
\hline X4-7 & 1 & X4-7 & 2 & X4-7 & 1 & X4-7 & 1 \\
\hline X5-1 & 2 & X5-1 & 5 & X5-1 & 4 & X5-1 & 4 \\
\hline X5-2 & 1 & X5-2 & 3 & X5-2 & 3 & X5-2 & 3 \\
\hline X5-3 & 1 & X5-3 & 1 & X5-3 & 2 & X5-3 & 2 \\
\hline
\end{tabular}


Table 6: A comparison among and Averages and standard divisions for the studied items

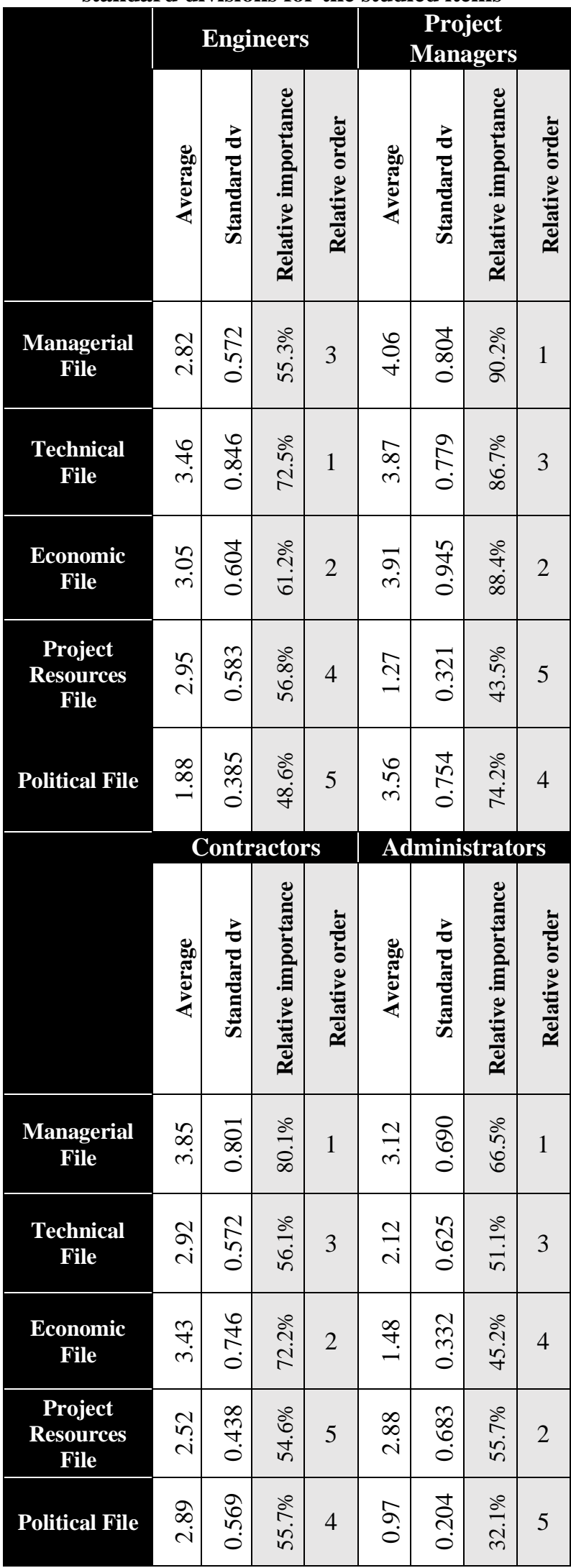

After conducting the independent samples T-Test, the research concludes that the relative order of assessed files (FFP) is the first ranked file if the Managerial file, whereas, the least importance one is the Political File as clarified in the following table:

Table 7: Relative frequency distribution table for each

\begin{tabular}{|c|c|c|c|}
\hline \multicolumn{5}{|c|}{ file } \\
\hline $\begin{array}{c}\text { Managerial } \\
\text { File }\end{array}$ & 18 & 28.0 & 28.0 \\
\hline $\begin{array}{c}\text { Technical } \\
\text { File }\end{array}$ & 12 & 18.0 & 46.0 \\
\hline $\begin{array}{c}\text { Economic } \\
\text { File }\end{array}$ & 15 & 23.0 & 69.0 \\
\hline $\begin{array}{c}\text { Project } \\
\text { Resources } \\
\text { File }\end{array}$ & 11 & 17.0 & 86.0 \\
\hline $\begin{array}{c}\text { Political } \\
\text { File }\end{array}$ & 9 & 14.0 & 100.0 \\
\hline Total & 65 & 100.0 & \\
\hline
\end{tabular}

So that, the research can determine the major standards for contractor evaluation and their percentages for contractor evaluation as clarified in the Fig.7 as follow:

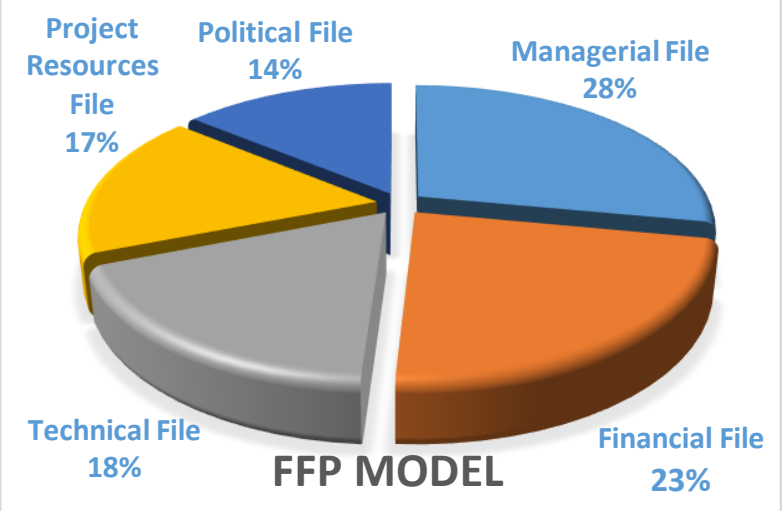

Figure 7: Major standards for contractor evaluation

Table 8: Distribution of factors in FFP model

\begin{tabular}{|c|c|c|}
\hline File & Percentage of file & $\begin{array}{c}\text { No. of } \\
\text { factors }\end{array}$ \\
\hline $\begin{array}{c}\text { Managerial } \\
\text { File }\end{array}$ & $28 \%$ & 8 \\
\hline $\begin{array}{c}\text { Economic } \\
\text { File }\end{array}$ & $23 \%$ & 7 \\
\hline $\begin{array}{c}\text { Technical } \\
\text { File }\end{array}$ & $18 \%$ & 12 \\
$\begin{array}{c}\text { Project } \\
\text { Resources } \\
\text { File }\end{array}$ & $17 \%$ & 7 \\
\hline Political File & $14 \%$ & 3 \\
\hline
\end{tabular}

From the tables $(6 \& 8)$ the top ranked files are (Managerial file, Economic file \& technical file) according to their values of relative importance, consequently, AHP method will compare the contractors depending on those top 3 files in FFP. Besides, CPMCE depends on the questionnaire attached in Appendix (A) to 
evaluate contractors according to their scores in the files of (FFP) model as clarified in the following Figs (7\&8):

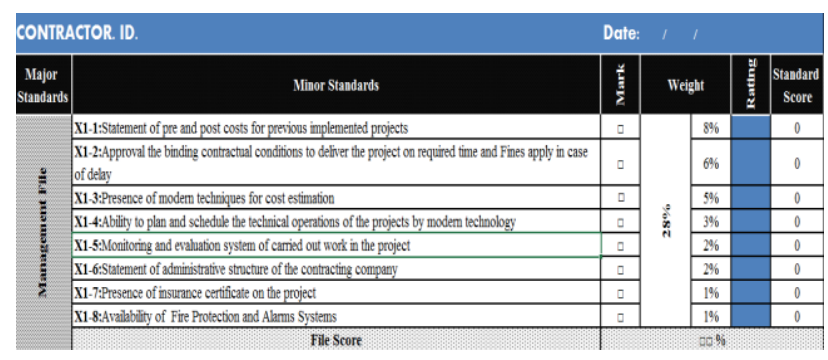

Figure 8: Upper part of assessment form in CPMCE

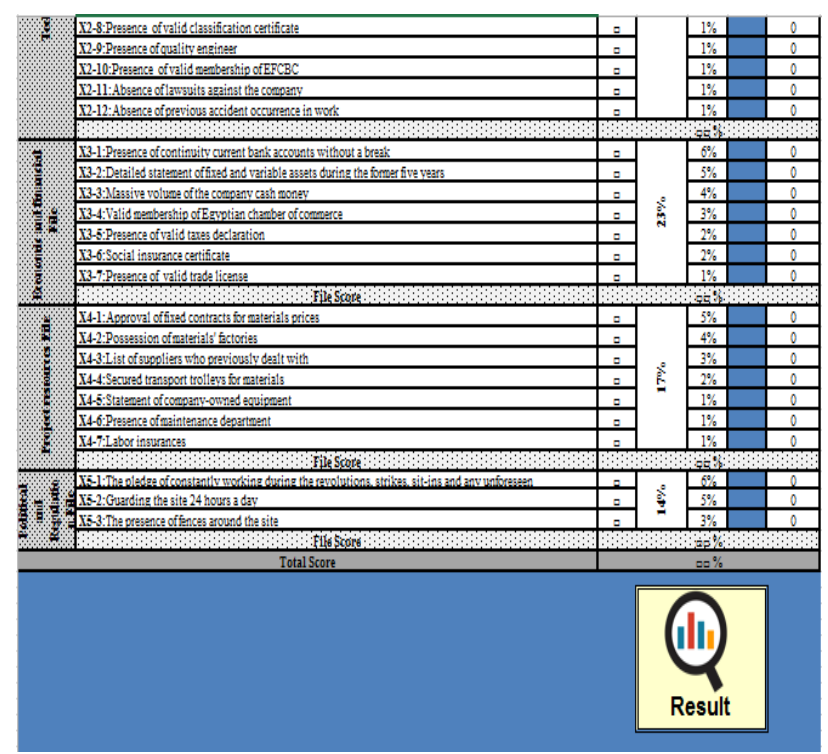

Figure 9: Lower part of assessment form in CPMCE

After filling the FFP model as previously mentioned, the (CPMCE) will assume the winner bidder within conducting a comparison which based on AHP method that can tradeoff among the applied contractors within their final results of assessment, finally, showing the ranking of contractors in a descending order by choosing the best 3 contractors $\left(1^{\text {st }}, 2^{\text {nd }}\right.$ and, $\left.3^{\text {rd }}\right)$ Consecutively as shown in the following figure:

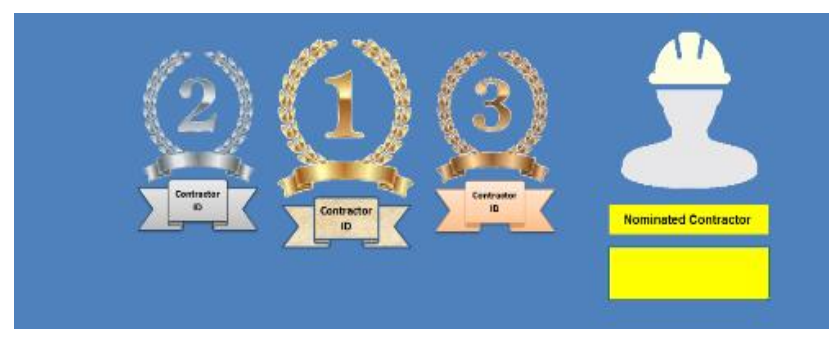

Figure 10: Result of assessment process

The (CPMCE) show the top three ranked contractors not the first one only to give alternatives in case of the winner contractor's withdrawal or occurrence of any problem might stop the work continuation.

\section{RESULTS AND DISCUSSION}

\subsection{Results of the literature review of previous studies}

a-The lowest price of bid is not a condition the foremost financial solution over long term plan; the only dependence on bid prices a tradeoff among contractors is somewhat risky and shortsighted.

b- Construction project sort of a chain and therefore the bad choice of contractors affects the entire chain with undesirable influences on all activities of construction project.

c- The best price with a higher-quality contractor might be obtained by practicing appropriate contractorevaluation techniques instead of using traditional method; using a scientific method to achieve the right evaluation to contender contractors and emphasis on the past experience. In other words, improving contract safety performance of contractors.

d- Low tender value could seem catchy to the customer at tendering process, but, the project might face obstacles if the contractor is unable to complete the work on the determined time (project time line) or compromises on the construction's quality to scale back the actual cost. e- Prequalification may be what's before the process of tender wont to check and evaluate the ability of contractor to satisfy the requirements of contract during a favorable way in case of awarding to them as proper emphasis on past experience and spend so far technology utilization, the accessible construction methods particularly.

\subsection{The results of the questionnaire analysis}

a- The findings of questionnaire clarified that the foremost common indicators considered by procurers within the bid process are concerning financial situation, technical ability, project resources, managerial aspects, and political impacts.

b-All samples of research society affirmed that managerial file has no less importance than financial and technical files.

c-Most of respondents recommended with giving the contractors extra time to bid projects might lead to set actual bid prices. As, contractors have exceeded time to revise their plans, besides, have quotes from a group of subcontractors and suppliers in setting bids. Contractors might select to not bid when the time determined for bidding is very short.

d-Few of respondents neglected the impact of political items in (FFP) on the process of contractors' assessment.

\subsection{The results of (CPMCE)}

a- The efficiency of AHP in assessment process that can help the owners of construction projects and decisionmakers in Egypt, by nominating the experienced and appropriate contractors.

b- Avoidance the donor policy in bidding in traditional way to the lowest bid to assess bidders support the 
technical, managerial, economic, project resources and political aspects.

c- Proposing a replacement alternate nomination model for a comprehensive assessment of contractors. As, it targets to choose the proper contractor who can do his work effectively for a satisfied price, and may confirm the items as follow:

- A good reputation permanently for work man ship and client organization

- Adhering to the tenet of quality first and the project timeline.

- A strong financial situation with an acceptable business record

- A suitable former experience in the same sort and size of the project.

d-CPMCE is not a complicated software as it designed on Microsoft Spread Sheet, so, it is easy to use.

\section{CONCLUSION}

In Egypt, the concept of contractor assessment with points is unfamiliar and that results in inappropriate selection, as, it is customary in construction manufacture to gain projects with the lowest price of bid. Some problems generated as contractors undertaking projects beyond their capacity, poor managerial structure of construction companies, poor technical structure of construction companies, poor performance of subcontractor and delay in project completion time. Thus, without domination the cost influencing indicators, construction companies will not be able to monitor the expenses effectively, which will in turn growth the project costs and affect the total gain. In addition, the factor of Donor policy in bidding to the lowest price is one of the most influencing factors in executed construction projects according to previous study for the researcher.

The current study presents an idea of how-to nominate contractors (bidders) in Egypt within suggesting a new assessment tool named (CPMCE) that can define criteria weights for the bidders and nominating the top 3 ranked bidders. So, it can solve the insufficiency of the donor policy to the lowest price bid, consequently, CPMCE can enable the owners of choosing the right contractor who able to execute the project within its planned cost and planned duration to be a successful project. Consequently, this document (FFP) contains 5 files can evaluate the contractor from the perspective of the general groups as technical - $18 \%$, financial $-23 \%$, political $-14 \%$, managerial - $28 \%$ and project resources - $17 \%$ and allocates these groups with their impact values result from regression analysis as shown in appendix (A). Finally, AHP Method can nominate the winner of the tender

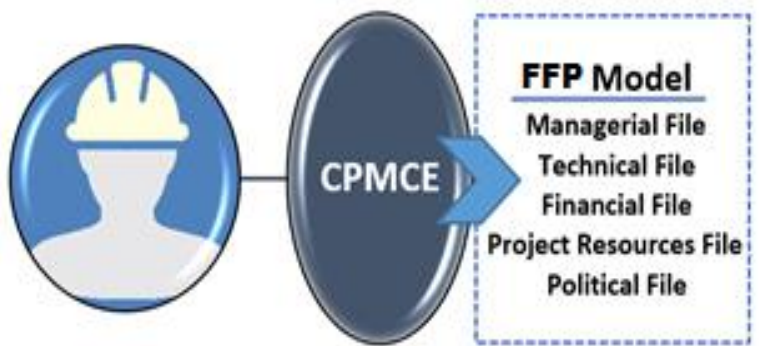

Figure 11: Elements of five files profile assessment model

Hence, choice of contractor must be made on a value for price basis, with suitable weighting of criteria as former experience and, performance within AHP method that can compare among the nominated contractors.

\section{RECOMMENDATIONS}

1. There is a serious need to edit the law no 89 for 1998 concerning the cancellation of tender system, the donor policy of bidding, the value of temporary and final insurance and the valid period for the reimbursement of contractor's Dues.

2. There is an urgent need for training, innovation and progress in the use of recent technology hence, a neediness to turning more and various risks to contractors, have required wider evaluations of their former performance and appraisals of Technical and financial capabilities for them.

3. A database for all documented must be found and an annually updated information about the contractors.

4. Acceptance of cost saving offerings from bidders within bidding and construction phases. Hence, the bidders might be more encouraged to present such proposals when probable cost savings are divided, and it should be negotiated in contracts or meetings of stakeholders.

5. The need to provide a mechanism can know the financial strength of the contractor as well the financial liquidity and order him to bring documents renewed his financial position.

6. It must be found a mechanism linking the data of government institutions projects with each other to know the contracted contractors in addition to the ability of wanted contractors to make a contract with them.

7. Consultants should prove their abilities in addressing the claims properly to avoid the contractual claims, like expansion of time and cost claims (over budgeting).

8. Improving the process of contractor selection requires the following recommended items:

- Fix of the proper contractor selection process based on the model suggested.

- Regard of all indicators influencing as on the financial value in the decisive selection of contractors.

- Editing the weight of indicators based on the weight and priority acquired.

- Exclusion the Non-Specialized decision making in the allocating of the gaining tender. 
Nomenclature

CPMCE: Contractor's Prequalification MultiCriteria Evaluation

FFP: Five Files Profile

AHP: Analytical Hierarchy Process

Credit Authorship Contribution Statement

Walaa A. Yakoub: Conceptualization, Methodology, Writing - Original Draft, Formal analysis, Software, Resources, Investigation, Data Curation, Validation.

\section{Declaration of competing Interest}

The author declares that she has no known competing financial interests or personal relationships that could have appeared to influence the work reported in this paper.

\section{References}

[1] J.K. Pinto, D.P. Slevin and, B. English "Trust in projects: An empirical assessment of owner/contractor relationships". International Journal of Project Management, 2009, 27.6: 638-648.

[2] W. Yakoub."New Approach to control the cost of construction projects in Egypt". M.Sc. Thesis, Faculty of Engineering, Port Said, Egypt. 2016.

[3] C. H. Wong, G. D. Holt, \& P. Harris "Multi-criteria selection or lowest price? Investigation of UK construction clients' tender evaluation preferences". Engineering Construction and Architectural Management, 2001, 8(4), 257-271.

[4] P. Jaskowski, S. Biruk and R. Bucon. "Assessing contractor selection criteria weights with fuzzy AHP method application in group decision environment, Automation in Construction" 2001, Vol. 19, P: 120126.

[5] M. El-Shehaby, I. Nosair \& A. Sanad. "Risk assessment and analysis for the construction of offshore oil \& gas projects". Int. J. Sci. Res. Educ. 2014.

[6] M. M. Abdel-Hafeez, S. S. El-Attar, \& W. A. AbdelHafez, "Factors Leading to Cost Overrun Occurrence in Construction Projects". Port Said Engineering Research Journal, 20(1), 2016, pp.71-77.

[7] W. Baars, H. Harmsen, R. Kramer, L. Sesink, \& J. van Zundert. "Project management handbook". Data Archiving and Networked Services, The Hague, 2006.

[8] H. Kerzner "Project management: a systems approach to planning, scheduling, and controlling". John Wiley \& Sons. 2017.

[9] J. Edler \& E. Uyarra. "Public procurement of innovation. In Handbook of innovation in public services". Edward Elgar Publishing. 2013.

[10] Tenders and Auctions Law No. 89 of 1998, Ministry of Finance, Egypt.

[11] P. Fong and S. Choi. "Final contractor selection using the analytical hierarchy process. Construction Management and Economics", Vol.18, 2000. P: 547557.
[12] M. Mahdi, K. H. Heiza \& M. A. El-Sheikh "Contractor Capabilities Evaluation Model from Risk Perspective Using Analytic Network Process". ERJ. Engineering Research Journal, 41(1), 2018, 25-35.

[13] E. Shaqour "An approach to Control Cost overrun in Construction Projects of Egypt", Doctor Dissertation in Architecture Engineering, faculty of Engineering, Cairo University, Egypt. 2014.

[14] Project Management Institute (PMI) "A Guide to the Project Management Body of Knowledge (PMBOK Guide)", 4thed, ANSI/PMI 99-001-2008, 2008, pp. 273-312.

[15] G. Holt. "Which contractor selection methodology?" International Journal of Project Management Vol. 16, No. 3, 1998, pp. 153-164.

[16] H. Doloi "Analysis of pre-qualification criteria in contractor selection and their impacts on project success". Construction Management and Economics, 27(12), 2009, 1245-1263.

[17] M. Molla, and E. Asa, "Factors Influencing Contractor Prequalification Processes in Developing Countries". International Journal of Architecture, Engineering and Construction Vol 4, No 4, 2015, P: 233-246.

[18] D. Puri \& S. Tiwari. "Evaluating the criteria for contractors' selection and bid evaluation". International journal of engineering science invention, 3(7), 2014, 44-48.

[19] G.D. Holt, P.O. Olomolaiye, and F.C. Harris. "A review of contractor selection practice in the UK construction industry". Building and Environment, 30, 1995, 553-61.

[20] M. Kumaraswamy "Contractor Evaluation and Selection: a Hong Kong Perspective", Building and Environment, Vol. 31, No. 3, 1996, pp. 273-282.

[21] I. Mahdi, M. Riley, S. Fereig, and A. Alex. "A multicriteria approach to contractor selection", Engineering, Construction and Architectural Management Vol. 9, no1, 2002, p: 29-37.

[22] Cheng, W. L. Eddie \& L. Heng "Contractor Selection Using the Analytic Network Process". Construction Management and Economics, 22, 2004, 1021-32.

[23] TMS Elhag, AH Boussabaine, \& TMA Ballal. "Critical determinants of construction tendering costs: Quantity surveyors' standpoint”, International Journal of Project Management, 23(7), 2005, 538-545.

[24] L. Y. Shen, W. S. Lu, \& M. C. Yam. "Contractor key competitiveness indicators: a China study". Journal of construction engineering and management, 132(4), 2006, 416-424.

[25] A. Azimi, Y. Pouya \& Z. N. Mazaherizade. "Identify and Evaluate the Effective Indicators in Choose a Contractor to Finance Water and Wastewater Company Mashhad". Sixth International Conference of Iranian Operations Research Society. 2013.

[26] S. L. Hsueh, \& M. R. Yan, "A multi-methodology contractor assessment model for facilitating green innovation: the view of energy and environmental protection". The Scientific World Journal, 2013.

[27] R. Ruparathna, \& K. Hewage. "Sustainable procurement in the Canadian construction industry: 
current practices, drivers and opportunities". Journal of Cleaner Production, 109, 2015, 305-314.

[28] S. Deep, S. Deepak, \& A. A. Syed. "A Review of Contract Awards to Lowest Bidder in Indian Construction Projects via Case Based Approach". Scientific Research Publishing, 3292, 2017, 159-68.

[29] A. Leśniak, D. Kubek, E. Plebankiewicz, K. Zima, \& S. Belniak. "Fuzzy AHP application for supporting contractors' bidding decision". Symmetry, 10(11), 2018, 642.

[30] A. Hoseinpoor, \& M. Alborzi, "The combination of DEA and AHP approach in the selection of contractors participating in tenders". HOLOS, 2, 2019, $1-15$.

[31] M. Y. Cheng, S. H. Yeh, \& W. C. Chang. "MultiCriteria Decision Making of Contractor Selection in
Mass Rapid Transit Station Development Using Bayesian Fuzzy Prospect Model". Sustainability, 12(11), 2020.

[32] J. K. Kumar \& S. V. Raj "Bid decision model for construction projects-A review". Materials Today: Proceedings, 22, 2020, 688-690.

[33] Z. Hatush, and M. Skitmore. "Criteria for contractor selection". Construction Management and Economics, Vol. 15, 1997, P: 19-38.

[34] G. Kalton \& I. Flores-Cervantes. "Weighting methods". Journal of official statistics, 19(2), 2003, 81.

[35] R. Mulcahy. "PMP Exam Prep: Rita's Course in a Book for Passing the PMP Exam Paperback, Eighth Edition, RMC Publications, USA. 2013. Online: www.RMCLS.com. Access: 11-5-2020.

\section{APPENDIX (A): THE PROPOSED MODEL OF CONTRACTOR'S ASSESSMENT (FFP CHECKLIST)}

\begin{tabular}{|c|c|c|c|c|c|}
\hline \multicolumn{2}{|c|}{ CONTRACTOR. ID. } & & & & \\
\hline $\begin{array}{c}\text { Major } \\
\text { Standards }\end{array}$ & Minor Standards & \multirow{2}{*}{$\sum_{\square}$} & \multicolumn{2}{|c|}{ Weight } & $\begin{array}{l}\text { Standard } \\
\text { Score }\end{array}$ \\
\hline \multirow{9}{*}{ 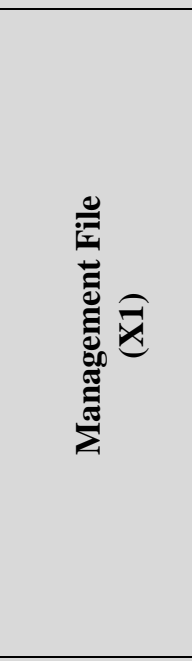 } & $\begin{array}{l}\text { X1-1: Statement of pre and post costs for previous } \\
\text { implemented projects }\end{array}$ & & \multirow{8}{*}{$\begin{array}{l}\stackrel{0}{\infty} \\
\stackrel{\sim}{\infty}\end{array}$} & $8 \%$ & \\
\hline & $\begin{array}{l}\text { X1-2: Approval the binding contractual conditions to } \\
\text { deliver the project on required time and Fines apply in } \\
\text { case of delay }\end{array}$ & $\square$ & & $6 \%$ & \\
\hline & X1-3: Presence of modern techniques for cost estimation & $\square$ & & $5 \%$ & \\
\hline & $\begin{array}{l}\text { X1-4: Ability to plan and schedule the technical } \\
\text { operations of the projects by modern technology }\end{array}$ & $\square$ & & $3 \%$ & \\
\hline & $\begin{array}{l}\text { X1-5: Monitoring and evaluation system of carried out } \\
\text { work in the project }\end{array}$ & $\square$ & & $2 \%$ & \\
\hline & $\begin{array}{l}\text { X1-6: Statement of administrative structure of the } \\
\text { contracting company }\end{array}$ & $\square$ & & $2 \%$ & \\
\hline & X1-7: Presence of insurance certificate on the project & $\square$ & & $1 \%$ & \\
\hline & X1-8: Availability of Fire Protection and Alarms Systems & $\square$ & & $1 \%$ & \\
\hline & File Score & & & & \\
\hline \multirow{11}{*}{ 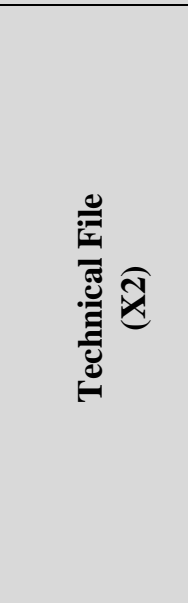 } & X2-1: Presence of value estimator & $\square$ & & $3 \%$ & \\
\hline & $\begin{array}{l}\text { X2-2: Statement of technical structure of the contracting } \\
\text { company }\end{array}$ & $\square$ & \multirow{10}{*}{$\stackrel{\circ}{\infty}$} & $2 \%$ & \\
\hline & X2-3: Presence of risk management department & $\square$ & & $2 \%$ & \\
\hline & $\begin{array}{l}\text { X2-4: The pledge of doing all required soil tests and site } \\
\text { investigation }\end{array}$ & $\square$ & & $2 \%$ & \\
\hline & X2-5: Presence of experienced supervisors ( $\geq 10$ years) & $\square$ & & $2 \%$ & \\
\hline & X2-6: Presence of the work experience certificate model & $\square$ & & $1 \%$ & \\
\hline & X2-7: Dealing with trustworthy subcontractors & $\square$ & & $1 \%$ & \\
\hline & X2-8: Presence of valid classification certificate & $\square$ & & $1 \%$ & \\
\hline & X2-9: Presence of quality engineer & $\square$ & & $1 \%$ & \\
\hline & X2-10: Presence of valid membership of EFCBC & $\square$ & & $1 \%$ & \\
\hline & X2-11: Absence of lawsuits against the company & $\square$ & & $1 \%$ & \\
\hline
\end{tabular}




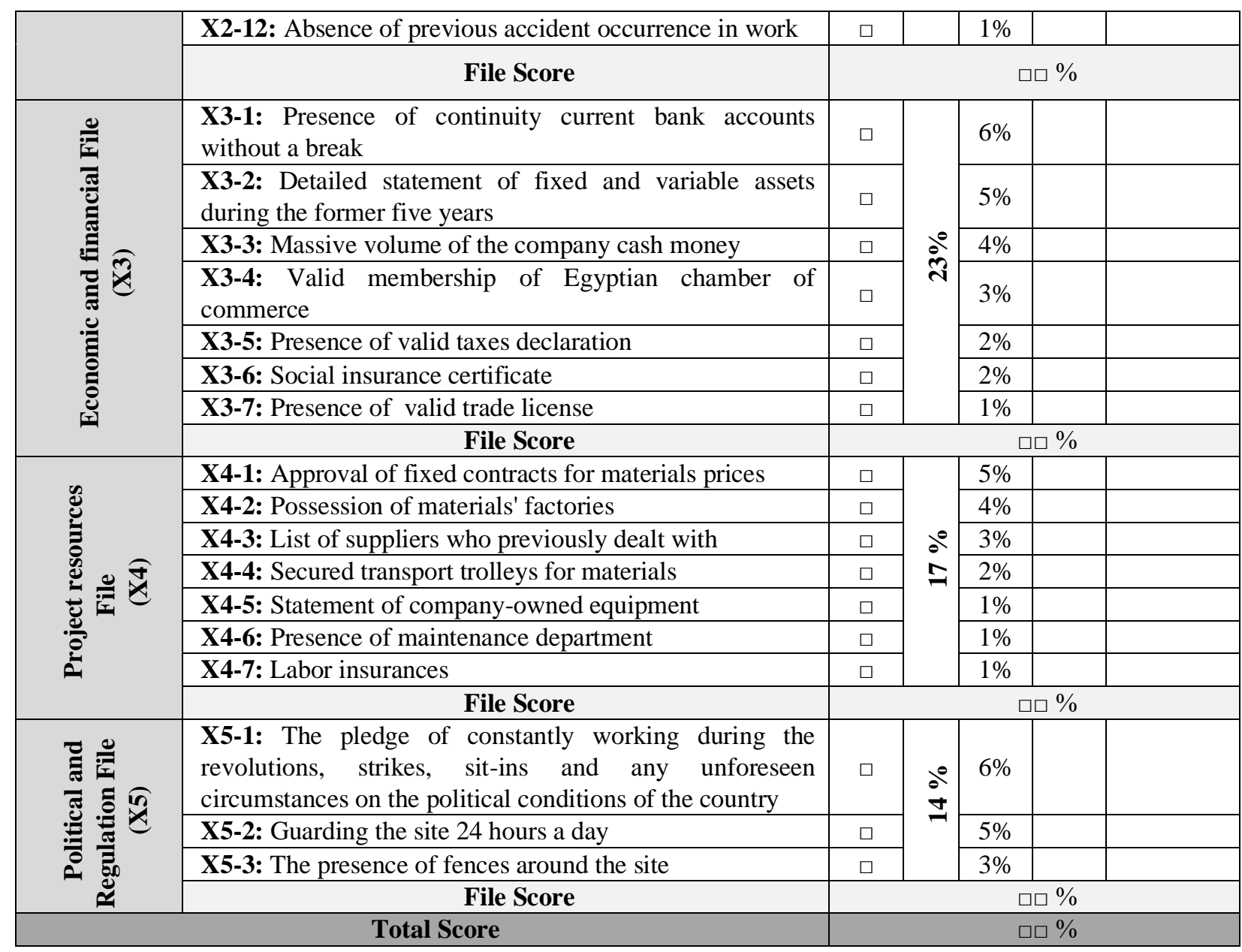

- Name:

- Signature:

- Date: / / 